\title{
THE ROLE OF ELEMENTARY SCHOOL TEACHERS IN CHRISTIAN ETHICS FOR THE ESTABLISHMENT OF STUDENT CHARACTER
}

\author{
Finka Priscilasari ${ }^{1}$, Uniek Dini Damayati ${ }^{2}$, Sandy Ariawan ${ }^{3}$ \\ ${ }^{1,2}$ College Student of STIPAK Malang, ${ }^{3}$ Lecturer of STIPAK Malang \\ finka.priscilasari@stipakdh.ac.id
}

\begin{abstract}
Indonesian life is now facing a character crisis that is engulfing its younger generation. Therefore it is necessary to have the right character education to be able to overcome this. As a Christian, the Bible is the basis of character education. The character is shown by a person through his or her behavior and actions on a daily day. Good character must conform to the prevailing ethics, values, and norms in society. Understanding Christian ethics is very helpful for believers to be able to behave and show their Christianity. For sumba students who are predominantly Christian and are now studying in Malang also experience this character problem. The purpose of this study is to analyze the teacher's knowledge in Christian ethics (sex education) against the character of the learner. In this paper, researchers used quantitative methods and found that the influence of Christian ethics on the Christian character of Sumba students in Malang was 19.5\%. There is a relationship between Christian ethics learning and significant Christian character and from positive correlation values it can be said, the higher in providing Christian ethics lessons and discussion learning methods, the higher the Christian character of sumba students in Malang Therefore researchers argue that Christian ethics teaching education is very important to be considered in the organization that has been formed, considering that the organization is majority Christian. One method that can be used in this learning is the discussion method.
\end{abstract}

Keywords: Christian ethics, character, method of discussion

\section{Introduction}

In living daily life, Christians must demonstrate their Christian ethics. This Christian ethic must be in line with the ethical actions and responsibilities that follow it as Christians. The Bible as the basis of instructions and commandments on Christian values, morals and character that believers must hold.

In Indonesia there are various character problems that plague the younger generation. The number of minors who have smoked, drank and drugs (Fajarini, 2014). There are also problems with pre-marriage sex, according to research (Inscription 2019) 33 percent of 500 teenagers in five major cities in Indonesia have had penetrative sex at the age of 18 to 20 years. By looking at these results, it is necessary for teachers to take immediate steps to help underage 
students not to have sex before their time.

What an educator must understand to guide students:

\section{A. Christian Ethics}

1. Understanding Ethics in general

Ethics, etymologically derived from Greek meaning habit or behavior. According to (Sandy Ariawan, 2020), ethics relates to the habits and ordinances of a person's good life either to himself or to society. Ethics contains orders that must be obeyed and prohibitions that must be avoided, if the ban is violated then it will be penalized in accordance with the rules, laws or norms that apply (Damayanti, 2016).

\section{Understanding Christian Ethics}

Christian ethics is a guide or teaching of god's desired deeds, which is based on values that conform to the nature of God, so christians do good deeds in response to god-conferred salvation. According to (Mealey, 2009) that Christian ethics is an explanation of how to act or how to act in accordance with biblical teachings and have the purpose to act differently to un believers, such as acting honestly in all things. Christian ethics goes against teaching, explanation, and instruction to do good deeds where the Bible is the foundation and source of the commandments to do good. Based on the above understanding of Christian ethics is the teaching of the behavior and attitude of Christians, of which God is central and Christ is an example to practice the values of faith in daily life, and the Bible becomes the basis or instruction of Christians in seeing all the good and true rules.

Characteristics of Christian ethics as conveyed (Geisler, 2015) that Christian ethics are based on God's will, commanded by God himself in accordance with the nature of God and all commandments are in the Bible. Because as a Christian it is supposed to be good and proper behavior to conform to what God wants and the behavior that God wants is all contained in the Bible recorded in detail.

\section{Christian Ethics Indicators}

In this study, Giesler used christian ethics indicators, namely:
A. Christian ethics that God wants.
B. Christian ethics are absolute.
C. Christian Ethics based on The Revelation of God.

D. Christian ethics is god's decree.

E. Christian ethics are Deontological. (True action is an obligation and is the main demand of Christians.)

\section{Ethical Benefits}

Ethics is useful to provide knowledge of the rules that apply so that people have the right actions and can determine which are right and wrong.

\section{B. Sex Education}

\section{Understanding Education}

$\mathrm{Ki}$ Hajar Dewantara argues that education means efforts to advance the ethics, mind and physical of the child, in order to advance the perfection of life that is to live and bring the child to life in harmony with nature and society. (Nurcholis, 2013) argues that education is an effort to lead the child from birth to reach physical and spiritual maturity, in the interaction of nature and its environment. 


\section{Sex education}

According to Azis (2017) Sex education is an effort to provide knowledge and understanding and prevention efforts against deviant sex behaviors such as homosexuals and infidelity. Safita further (2013) argues that sex trafficking is more geared towards preventing the consequences of inappropriate sex behavior.

\section{Sex Education in biblical view.}

God created sex organ differences to distinguish gender between men and women. What the Lord made was "very good" (To lot 1:31). One of God's purposes for creating sex and sexuality in marriage is for reproduction (Js. 1:28). God designed sexual expression to be exclusive, intimate, permanent, exhilarating and binding. And God has established marriage to be the only vessel for such sexual expression (Js. 2:24-25). In other words, sex and sexuality are fundamentally good and should be respected, not to betabed or otherwise exploited.

\section{Learning Strategies}

It is a learning design prepared by teachers (materials, materials, methods) used in the delivery of learning to students. The goal is to make it easier for teachers to deliver materials so that students understand learning materials more easily in accordance with their goals.

Discussion is one of the methods that can be used in learning with direct interaction between educators and students as well as between students. In this method, the teacher gives the problem to the student to jointly solve the problem.

\section{Christian characters}

According to W.B Saunders, (1977:126) in (llham, 2020) a character is a real and different person's nature, demonstrated by his mannerisms. Whereas according to (Wyne,2011) the character marks a person's technical way to apply values of kindness through his actions and mannerisms. It can be concluded that a character is the behavior or actions of a person that is different from others influenced by the prevailing values or habits that exist within that person's environment.

Christian character according to (Dr. Yonas Muanley, 2019) is the establishment of positive traits in Christians based on biblical teachings. The example of the Christian character in the Bible is shown by joseph in Genesis 39:6-23, where it is told that Joseph had a sweet, beautiful nature, and refused to persuade Potifar's wife to him. Similarly, daniel's character in Book of Daniel 1:8 tells of Daniel's attitude not to defil himself with the king's meal and the wine the king drank.

Christian characters must differ from those who do not yet believe in Christ as the new identity of Christians. Christian character traits include: love, discipline, honesty. In Christianity it is strongly opposed to premarital sex because it is considered incompatible with biblical teachings.

\section{RESEARCH METHODS}

Types of Research

This type of research in research is quantitative research experimentation. In the study used experimental quasi - with a type of nonequivalent control group.

Figure 3.1: Research Design 
$01 \times 02$

\section{$\mathrm{O} 3 \mathrm{O} 4$}

Description:

$\mathrm{O} 1$ and $\mathrm{O} 3$ : Pretest (Christian ethics, sex education and character)

O2 : Postest (Christian ethics, sex education and character)

O4 : Groups that are not in control

Research Place and Time

This research will be conducted on sumba teachers in Malang and this research will be carried out in June to July 2020 .

Population

The population in this study is sumba teachers in Malang.

Sample

In this study, researchers used nonprobability sampling techniques with a purposive sampling approach.

Table 3.1: Number of Samples

\begin{tabular}{|l|l|l|}
\hline \multirow{2}{*}{$\begin{array}{l}\text { Jumlah } \\
\text { Keseluruhan }\end{array}$} & \multicolumn{2}{|l|}{ Jenis Kelamin } \\
\cline { 2 - 3 } & Laki-laki & Perempuan \\
\hline 50 orang & 34 orang & 16 orang \\
\hline
\end{tabular}

Research Variables

A research variable is the object of research or what is the point of concern of a study. The focus variable consists of two variables: a.) Free variables (In this study the free variables are Christian ethical learning based on discussion learning methods (X1) and (X2) discussion learning methods (Sex Education)). b)Bound variables (In this study the bound variables were sumba students in Malang, which became variable $Y$.)

\section{Research Instruments}

In this study, from each existing variable will be given a explanation, then determine the indicator to be measured, until it becomes a statement item, as seen below

\section{Data Collection Techniques}

In ways to collect research data, the authors used methods such as the following:

1. Observation Method

2. Questionnaire Method (Questionnaire)

3. Documentation method

4. Data Analysis Techniques

Instrument Validity Test: In this study the variables that will be measured are Christian ethics learning based on discussion learning methods (Sex Education) as well as character.

Table 3.5: Christian Ethics Validity Test

\begin{tabular}{|c|c|c|c|}
\hline $\begin{array}{l}\mathrm{N} \\
\mathrm{O}\end{array}$ & $\begin{array}{l}\text { Indikator Etika } \\
\text { Kristen }\end{array}$ & $\begin{array}{l}\text { Nomor } \\
\text { Butir }\end{array}$ & $\begin{array}{l}\text { Juml } \\
\text { ah }\end{array}$ \\
\hline 1 & $\begin{array}{l}\text { Etika Kristen } \\
\text { yang } \\
\text { dikehendaki } \\
\text { Allah }\end{array}$ & $\begin{array}{l}1,2,3,4,5 \\
, 6,7\end{array}$ & 7 \\
\hline 2 & $\begin{array}{l}\text { Etika Kristen itu } \\
\text { Absolut }\end{array}$ & $\begin{array}{l}8,9,10,1 \\
1,12,13,1 \\
4\end{array}$ & 7 \\
\hline 3 & $\begin{array}{l}\text { Etika Kristen } \\
\text { berdasarkan } \\
\text { Wahyu Allah }\end{array}$ & $\begin{array}{l}15,16,17 \\
18,19,2 \\
0,21,22\end{array}$ & 8 \\
\hline
\end{tabular}




\begin{tabular}{|l|l|l|l|}
\hline 4 & $\begin{array}{l}\text { Etika Kristen } \\
\text { merupakan } \\
\text { Ketetepan }\end{array}$ & $\begin{array}{l}23,24,25,2 \\
6,27,28\end{array}$ & \\
\hline 5 & Etika Kristen & $29,30,3$ & 6 \\
& bersifat & $1,32,33$, & \\
& Deontologis & 34 & \\
\hline \multicolumn{2}{|l|}{ Jumlah } & $\mathbf{3 4}$ & $\mathbf{3 4}$ \\
\hline
\end{tabular}

Reliability Test: performed to determine the determination of an instrument (measuring instrument) in measuring the same symptoms even at different times. To test reliability in research using the help of SPSS version 16, resulting in an Alpha Cronbach value.

Normality Test: aims to test whether in regression models, disruptor or residual variables have a normal distribution.

Heteroskedastisity Test: If a statistically significant independent variable affects a dependent variable, then there is an indication of Heteroskedasity occurring.

Multicolinete test: aims to test whether a regression model found a correlation between free (independent) variables.

Linearity Test: conducted to determine the linearity of the relationship between free variables (Christian ethics $\mathrm{X} 1$ ) and related variables (characters of Sumba learners in Malang $Y$ ) and to determine the significance of deviations from the linearity of the relationship.

Correlation Coefficient Test: if two variables have a relationship between a free variable and a related variable, then it is then expressed with the correlation coefficient. In Table 3.7 as follows:

\begin{tabular}{|l|l|}
\hline $\begin{array}{l}\text { Interval } \\
\text { Koefisien }\end{array}$ & $\begin{array}{l}\text { Tingkat } \\
\text { Hubungan }\end{array}$ \\
\hline
\end{tabular}

\begin{tabular}{|l|l|}
\hline & \\
\hline $0,00-0,199$ & sangat rendah \\
\hline $0,20-0,399$ & Rendah \\
\hline $0,40-0,599$ & Sedang \\
\hline $0,60-0,799$ & Kuat \\
\hline $0,80-1,000$ & sangat kuat \\
\hline
\end{tabular}

Hypothesis Testing

Regression Coefficient Test: This analysis to find out the direction of the relationship between an independent variable and a dependent variable is positive or negative and to predict the value of a dependent variable if the value of an independent variable is increted or decreased.

Partial Regression Coefficient Test ( $T$ test): The $t$ test is used to find out if in the regression model an independent variable partially affects the dependent variable.

\section{Research Procedures}

A research procedure is a series of activities carried out by a researcher systematically and regularly to achieve research objectives.

\section{RESEARCH RESULTS}

This research is quantitative where the resulting data will be in the form of numbers. This research has the aim of analyzing the teacher's knowledge in Christian ethics and the method of learning discussion (sex education) against the character of the learner.

The dissemination of questionnaires is done by pre test and post test as well as questionnaire measured using likert scale. This study used one independent 
variable, namely Christian ethics and the second variable as a way or method of conveying lessons as well as dependent variables that are the character of the learner. Questionnaires created with the variables studied had an average of 7 question items. The characteristics of the respondent are the variety of backgrounds that the respondent himself has.

Data Analysis : The instrument used for data collection in this study, which is in the form of a questionnaire with the total number of questions 48butir. After data collection, data analysis will be done using SPSS 16.0 software. Item Validity Test: used to measure whether or not a questionnaire is valid.

Table 4.2: Christian Ethical Validity Test

\begin{tabular}{|ll|l|}
\hline VAR00001 & Pearson Correlation & $520^{* *}$ \\
VAR00002 & Pearson Correlation & $.653^{* *}$ \\
VAR00003 & Pearson Correlation & $423^{* *}$ \\
VAR00004 & Pearson Correlation & $.566^{* *}$ \\
\hline VAR00005 & Pearson Correlation & $.529^{* *}$ \\
\hline VAR00006 & Pearson Correlation & $.440^{* *}$ \\
\hline VAR00007 & Pearson Correlation & $.393^{* *}$ \\
\hline VAR00008 & Pearson Correlation & $.530^{* *}$ \\
\hline VAR00009 & Pearson Correlation & $.425^{* *}$ \\
\hline VAR00010 & Pearson Correlation & $.506^{* *}$ \\
\hline VAR00011 & Pearson Correlation & $.623^{* *}$ \\
\hline VAR00012 & Pearson Correlation & $.611^{* *}$ \\
\hline VAR00013 & Pearson Correlation & $.588^{* *}$ \\
\hline
\end{tabular}

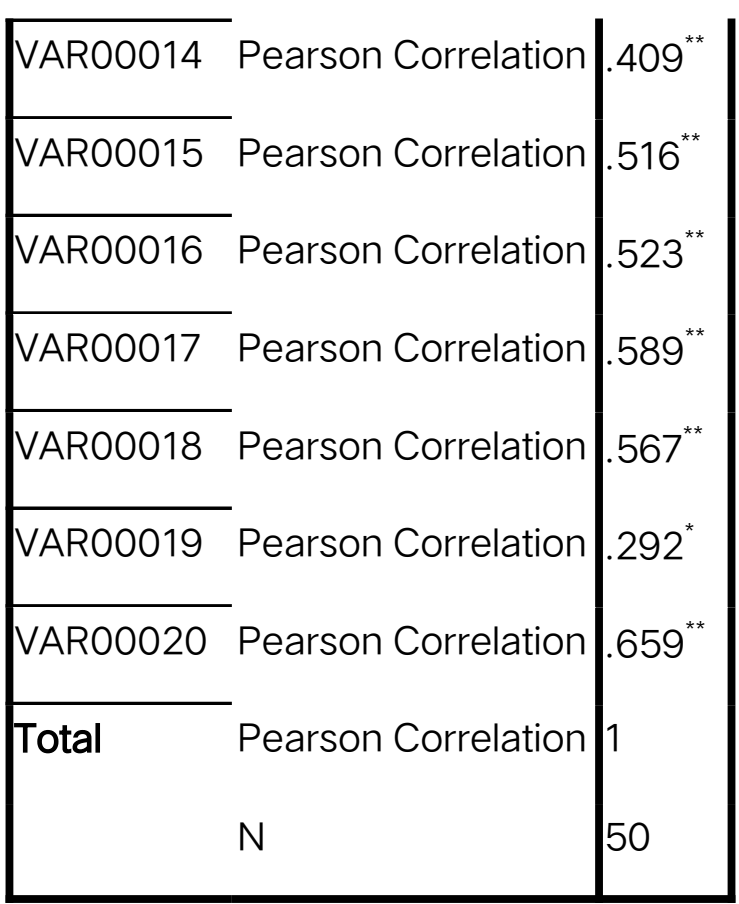

**. Correlation is significant at the 0.01 level (2-tailed).

*. Correlation is significant at the 0.05 level (2-tailed).

Reliability Test is how much the test degree measures consistently the target measured. Reliability is expressed in the form of numbers, usually as coefficients. Table 4.4: Christian Ethics Reliability Test

\section{Reliability Statistics}

\begin{tabular}{|l|l|}
\hline $\begin{array}{l}\text { Cronbach's } \\
\text { Alpha }\end{array}$ & $\begin{array}{l}\mathrm{N} \quad \text { of } \\
\text { Items }\end{array}$ \\
\hline 843 & 20 \\
\hline
\end{tabular}

From the output table above can be known the value of Cronbach's Alpha by 0.843 with the number of items item 20 . Since Cronbach's Alpha value is 0.843 and greater than 0.60 then it can be summed up 20 items of statements or questions about christian ethics are 
good and reliable.

Table 4.5: Christian Character Reliability Test

\begin{tabular}{|c|c|}
\hline $\begin{array}{l}\text { Cronbach's } \\
\text { Alpha }\end{array}$ & $\begin{array}{l}\mathrm{N} \\
\text { Items }\end{array}$ \\
\hline 616 & 10 \\
\hline
\end{tabular}

From the output table above can be known the value of Cronbach's Alpha by 0.616 with the number of items item 10 . Since Cronbach's Alpha value is 0.616 and still greater than 0.60 then it can be summed up 10 items of statements or questions about good and reliable Christian character.

Normality Test

Normality test procedures are carried out in the following ways:

Ho: Normal high data distribution

Ha: Abnormal high data distribution

The normality test kreteria is if the significance $\leq 0.05$ then $\mathrm{Ho}$ is rejected but if the significance $\geq 0.05$ then $\mathrm{Ho}$ is accepted.

Table 4.6: Data Normality Test

\begin{tabular}{|c|c|c|c|}
\hline & & $\begin{array}{l}\text { Etika } \\
\text { Kristen }\end{array}$ & $\begin{array}{l}\text { Karakter } \\
\text { Kristen }\end{array}$ \\
\hline $\mathrm{N}$ & & 50 & 50 \\
\hline Normal & Mean & 84.060 & 38.3400 \\
\hline & $\begin{array}{l}\text { Std. } \\
\text { Deviatio } \\
n\end{array}$ & 9.11247 & 4.91400 \\
\hline Most & Absolute & .089 & .109 \\
\hline
\end{tabular}

\begin{tabular}{|lr|l|l|} 
Extreme & Positive & .064 & .068 \\
Differences & Negative & -.089 & -.109 \\
Kolmogorov-Smirnov & .632 & .767 \\
$Z$ & & \\
Asymp. Sig. (2-tailed) & .820 & .598 \\
\hline
\end{tabular}

Based on the normality test output table using the Kolmogorov-Smirnov test data above, it can be noted that the item of Christian ethics items is 0.820 greater than 0.05. Similarly, christian character item items get a value of 0.598 greater than 0.05 .

Heteroskedastisity Test: According to Writing, (2019) that the heterosdekasity test aims to test whether in regression models there is a variant inequality of residual or other observations. Table 4.7: Heteroskedasticity Test

\begin{tabular}{|c|c|c|c|c|c|}
\hline \multirow[b]{2}{*}{ Model } & $\begin{array}{l}\text { Unst } \\
\text { ized } \\
\text { Coef }\end{array}$ & $\begin{array}{l}\text { tandard } \\
\text { fficients }\end{array}$ & $\begin{array}{l}\text { Standardi } \\
\text { zed } \\
\text { Coefficie } \\
\text { nts }\end{array}$ & \multirow[b]{2}{*}{ T } & \\
\hline & B & $\begin{array}{l}\text { Std. } \\
\text { Error }\end{array}$ & Beta & & Sig \\
\hline $\begin{array}{c}1 \text { (Consta } \\
\mathrm{nt} \text { ) }\end{array}$ & $\begin{array}{l}1.91 \\
2\end{array}$ & 3.836 & & $\begin{array}{l}.49 \\
8\end{array}$ & $\begin{array}{l}.62 \\
1\end{array}$ \\
\hline $\begin{array}{l}\text { Etika } \\
\text { Kristen }\end{array}$ & $\begin{array}{l}.02 \\
4\end{array}$ & .045 & .075 & $\begin{array}{l}.52 \\
0\end{array}$ & $\begin{array}{l}.60 \\
5\end{array}$ \\
\hline
\end{tabular}

Based on table 4.7 On christian ethical 
learning variables and Christian characters have a sig value greater than 0.05 then it can be said the data does not occur heteroskedastisitas.

Multicholinearity Test: To find out the absence of multicholinearity in the regression model can be seen from the value of Variance Inflation Factor (VIF). Table 4.8: Multicholineity Test

\section{Coefficients $^{a}$}

\begin{tabular}{|c|c|c|c|c|c|c|c|}
\hline \multirow[b]{2}{*}{ Model } & \multicolumn{2}{|c|}{$\begin{array}{l}\text { Unstand } \\
\text { ardized } \\
\text { Coeffici } \\
\text { ents }\end{array}$} & $\begin{array}{l}\text { Stand } \\
\text { ardize } \\
\text { d } \\
\text { Coeffi } \\
\text { cients }\end{array}$ & \multirow[b]{2}{*}{ t } & \multirow[b]{2}{*}{$\begin{array}{l}S i \\
g .\end{array}$} & \multicolumn{2}{|c|}{$\begin{array}{l}\text { Collinear } \\
\text { ity } \\
\text { Statistics }\end{array}$} \\
\hline & B & $\begin{array}{l}\text { Std. } \\
\text { Erro } \\
r\end{array}$ & Beta & & & $\begin{array}{l}\text { Toler } \\
\text { ance }\end{array}$ & $\begin{array}{l}\mathrm{VI} \\
\mathrm{F}\end{array}$ \\
\hline $\begin{array}{l}1 \text { (Con } \\
\text { stant } \\
\text { ) }\end{array}$ & $\begin{array}{l}44 . \\
27 \\
0\end{array}$ & $\begin{array}{l}6.5 \\
24\end{array}$ & & $\begin{array}{l}6 . \\
78 \\
6\end{array}$ & $\begin{array}{l}.0 \\
0 \\
0\end{array}$ & & \\
\hline $\begin{array}{l}\text { Etika } \\
\text { Krist } \\
\text { en }\end{array}$ & $\begin{array}{l}-.0 \\
71\end{array}$ & .077 & -.131 & $\begin{array}{l}-.9 \\
14\end{array}$ & $\begin{array}{l}3 \\
6 \\
5\end{array}$ & $\begin{array}{l}1.00 \\
0\end{array}$ & $\begin{array}{l}1 . \\
00 \\
0\end{array}$ \\
\hline
\end{tabular}

Based on the results of table 4.8 shows that both ethics and Christian characters have a tolerance value of more than 0.10 and a VIF value of less than 10 then it can be said that the data does not experience multicolinearity in the regression model.

Linearity Test : Testing on SPSS using Test for Linearity with a significance level of 0.05. Two variables are said to have a linear relationship when linearity is less than 0.05 .

Table 4.9: Linearity Test

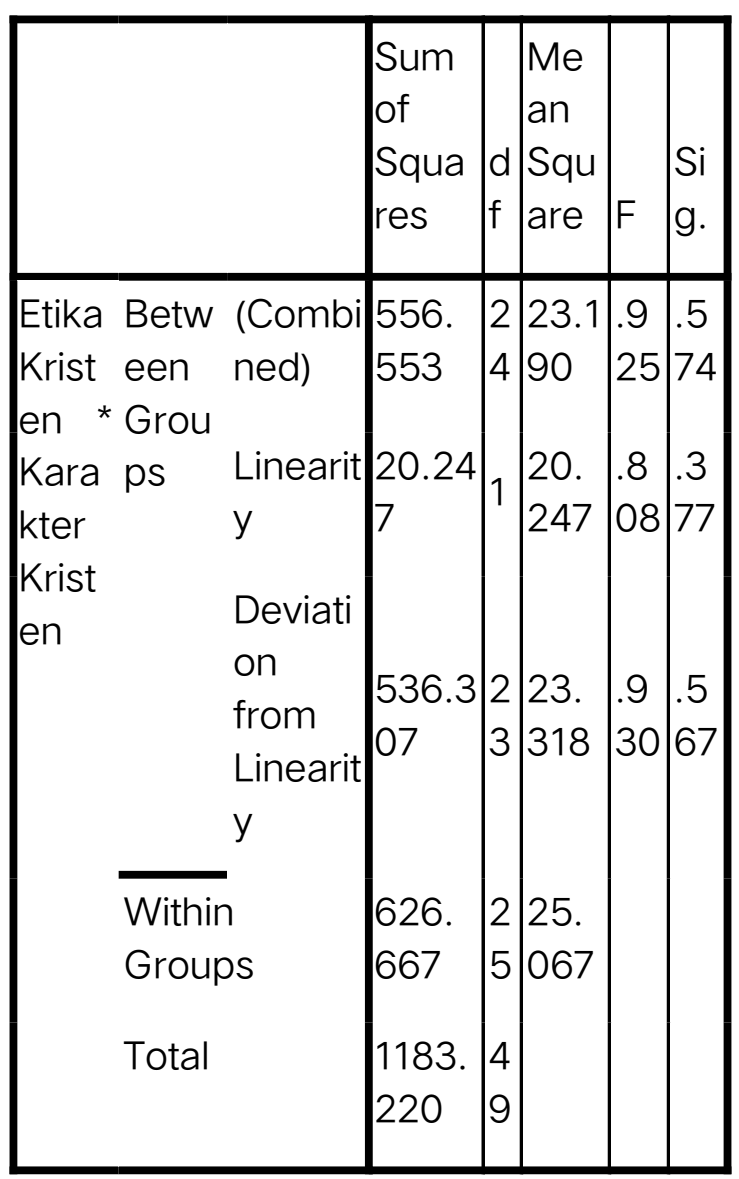

From the output table above it can be noted that the significance value in Linearity is 0.567 . It is concluded that between christian ethical variables and Christian characters there is a linear relationship.

\section{Correlation Test}

The study used a simple correlation with Pearson's Product Moment formula.

Table 4.10: Correlation Test

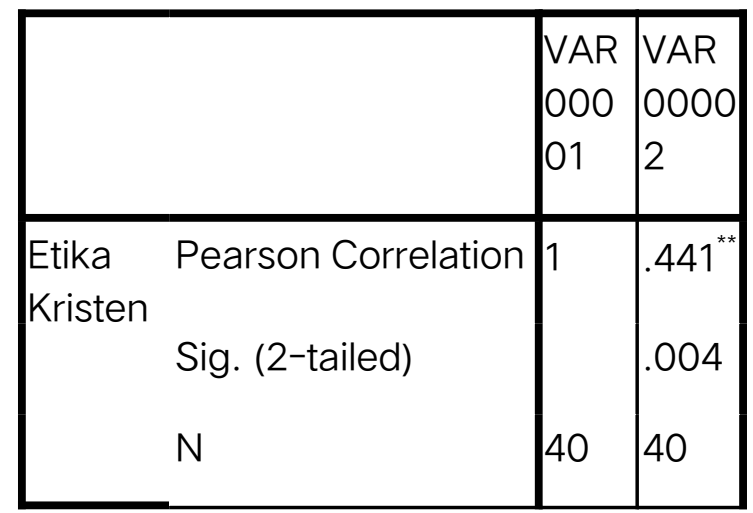




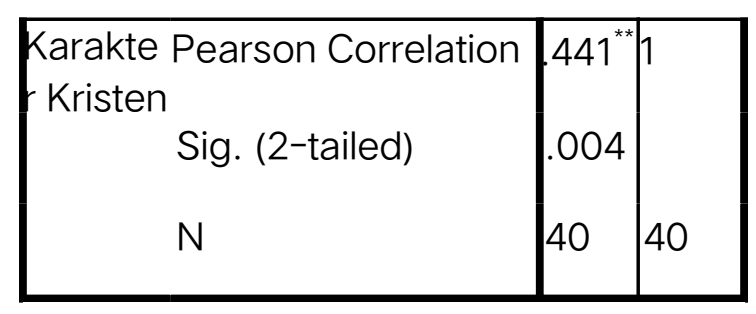

**. Correlation is significant at the 0.01 level (2-tailed).

Based on table 4.10 of the correlation test calculation between Christian ethical variables and Christian characters this correlation value of 0.441 figures shows that there is a positive and strong relationship between Christian ethics and Christian character.

Based on the output data in table 4.10, there is a significance (Sig. 2-tailed) of Christian ethics with a Christian character as low as 0.004 . Singnifikansi $\leq 0.05$ so Ho was rejected.

Research Hypothesis Testing

Regression Test.

Table 4.10: Regression Test

\begin{tabular}{|c|c|c|c|c|c|}
\hline \multirow[b]{2}{*}{ Model } & \multicolumn{2}{|c|}{$\begin{array}{l}\text { Unstandar } \\
\text { dized } \\
\text { Coefficient } \\
\text { S }\end{array}$} & $\begin{array}{l}\text { Standard } \\
\text { ized } \\
\text { Coefficie } \\
\text { nts }\end{array}$ & & \\
\hline & B & $\begin{array}{l}\text { Std. } \\
\text { Error }\end{array}$ & Beta & $\mathrm{T}$ & $\begin{array}{l}\text { Si } \\
\text { g. }\end{array}$ \\
\hline $\begin{array}{c}1 \text { (Const } \\
\text { ant) }\end{array}$ & $\begin{array}{l}31.3 \\
32\end{array}$ & 6.796 & & $\begin{array}{l}4.6 \\
11\end{array}$ & $\begin{array}{l}.0 \\
00\end{array}$ \\
\hline $\begin{array}{l}\text { Etika } \\
\text { Kristen }\end{array}$ & .170 & .056 & .441 & $\begin{array}{l}3.0 \\
30\end{array}$ & $\begin{array}{l}.0 \\
04\end{array}$ \\
\hline
\end{tabular}

Coefficient $b$ is called the regression direction coefficient and states the change in variable $\mathrm{Y}$ for each variable change $X$. This change is an increase when $b$ is marked positive and decreases when $b$ is marked negative. Based on the regression test results in table 4.11 a constant value of (a) of 31,332 states that if there is no Christian ethical value then the Christian character value is 31,332. Furthermore, the regression test results in table 4.11 obtained a Christian ethical coefficient value (b) of 0.170 stating that each addition of 1 Christian ethical value then the value of Christian character increased by 0.170 .

Test $\mathrm{t}$

To test the hypothetical coefficient: $\mathrm{Ho}=$ 0 . therefore the steps used to test the hypothesis with the t test are as follows:

Determining hypotheses

Specify a t count

Specify t table

Kreteria testing

Based on the test creater, it gets a table $t$ count value of $3,030>2,011$ then $\mathrm{Ho}$ is rejected. Thus, it can be concluded that Christian ethics have a positive effect.

Table 4.12 Regression Test

\begin{tabular}{|l|l|l|l|l|}
\hline $\begin{array}{l}\text { Mod } \\
\text { el }\end{array}$ & $R$ & $\begin{array}{l}\text { R } \\
\text { Squar }\end{array}$ & $\begin{array}{l}\text { Adjusted } \\
\text { R Square }\end{array}$ & $\begin{array}{l}\text { Std. Error } \\
\text { of the } \\
\text { Estimate }\end{array}$ \\
\hline 1 & .441 & .195 & .173 & 2.92033 \\
\hline
\end{tabular}

Based on the outpot table 4.12 above shows the value of $\mathrm{R}$ Square (R2) or determination value. The value of Christian R2ethics is 0.195 or $19.5 \%$ in the sense of the contribution of the 
contribution of the influence of variable $X$ or Christian ethics to the Christian character of 19.5

\section{Discussion}

The relationship between Christian ethics learning and significant Christian character and of positive correlation values can be said, the higher the christian ethics lesson and the method of discussion learning, the higher the teacher's understanding in developing the character of the learner. In this study, it illustrates that Christian ethics learning taught by discussion learning methods is very useful for Christian characters. Christian ethics studies are tasked with investigating, correcting, controlling, and directing about what to do and what not to do. The benchmark for doing good deeds is based on the decree of Jesus Christ or the teachings of the Bible. The need for christian character formation factors that are to pay attention to the cognitive factors and age factors of each child so as to convey lessons about Christian character using relevant approach methods. Family or parent as the formation of the first and fore master character in the child's life, where the parent must be a good example to his children. In character formation there are several factors that are very influential in the process of character formation, such as moral disposition, in school, in the community environment and in the family environment and family plays an important role in shaping the character of a child.

Thus learning about Christian ethics is one of learning about the right things that should be done, so the function of Christian ethics is to bring back to the real truth. Good ethics will change the way a person views themselves in taking action or in behaving.

Use of Discussion Methods on Christian ethics learning

In the formation of Christian characters using the method of discussion learning shows that there is a positive and strong relationship between Christian ethics and Christian character using discussion learning methods. After obtaining the correlation value then it should also look at the value of significance which explains that there really is an influence of Christian ethics on christian character using discussion learning methods. It can be concluded that the relationship between Christian ethics and Christian character in using a significant discussion learning motto and from a positive correlation value, it can be said, the higher in providing Christian ethics lessons based on discussion learning methods, the higher the understanding of teachers to develop the character of students. Similarly, if the lower the christian ethics learning, the lower the Christian character that students will get from the teacher.

\section{Biblical view}

One example of Christian ethical principles can be seen in man's relationship with God from the beginning of J.J. 2:17 There are commandments or teachings given by God to man so that man may keep his behavior by not eating the tree fruit of knowledge of good and evil. Similarly, Christian ethics must continue to be taught so that every believer understands and makes ethical values as teachings or norms that influence daily conduct. In establishing or shaping the character Paul explains in Romans 12:2 explaining that as a Christian there must be a change of 
mind so that in erating according to God's will. So that in the christian ethics lesson given has a clear goal, namely a change of mind in order to understand which behavior is in accordance with God's will. Colossion 3:17 This text of the Bible gives the understanding that every Christian must have words and deeds that trouble God in all aspects of life. So when Christian ethics learning is taught that every believer has good words and deeds to care for God in every aspect of life.

\section{Conclusion}

Christian ethics is a response to god's grace and work that has saved man from sin. The reference point of Christian ethics is the truth of god's word expressed in the Bible, something that leads to the word of God. It means that something right will not go against the word of God.Christian ethics are not only abstract rules but there are also real examples of Christian ethics in the Bible, whether in well-done rules or commandments or behavior in violation of God's rules or commandments. It's something educators should teach students.

\section{References}

Aminudin, M. (2019, Oktober 29). Dua Kelompok Pemuda Tawuran di Malang Adalah Mahasiswa, 3 Orang Diamankan.

Ariawan, S. (2020). Etika Guru Pendidikan Agama Kristen. Banyumas: CV. Pena Persada. Ariawan, S. (2020). Virtual Discussion for Improving Motivation: A
Christian Education Strategy against Covid-19 Pandemic Effect. Internatinal Research Journal on Advanced Science Hub, 2(7), 1-5.

http://dx.doi.org/10.47392/irjash.202 0.56

Damayanti, P. \&. (2016). Pengaruh Idealisme, Relativisme, Pengetahuan, Gender dan Umur pada Perilaku Tidak Etis Akuntan. E- Jurnal Akuntansi Universitas Udayana.

Dr. Yonas Muanley, S. M. (2019, Agustus 6). Pembentukan karakter Kristen.

Fajarini, U. (2014). Peranan Kearifan Lokal Dalam Pendidikan Karakter. Sosio Didaktika.

Ilham, M. (2020, Februari 22). Pengertian Karakter Menurut Para Ahli Terlengkap.

Mealey, A. M. (2009). The ldentity of Christian Morality. Burlington: Ashgate Publishing.

Nurcholis. (2013). Pendidikan Dalam Upaya Memajukan Teknologi. Jurnal

Kependidikan.Ariawan,Sandy (2020).Etika Guru Pendidikan Agama Kristen.Purwokerto Selatan:Pena Persada. 